\title{
Natural Adsorbent Made from Eggshells for Removal of Chromium (VI) in Water
}

\author{
Amirul Faiz Abdul Latif 1,", Loh Siew Yee ${ }^{2}$, Mimi Suliza Muhamad ${ }^{1}{ }^{(D)}$, Lee Te Chuan ${ }^{2}$ (D), \\ Hatijah Basri 3 (iD)
}

1 Department of Civil Engineering Technology, Faculty of Civil Engineering Technology, University Tun Hussein Onn Malaysia, Pagoh Education Hub, 84600, Pagoh, Muar, Johor, Malaysia; amirulfaizabdlatif@gmail.com (A.F.A.L.); msuliza@uthm.edu.my (M.S.M.);

2 Department of Production and Operation Management, Faculty of Technology Management and Business, University Tun Hussein Onn Malaysia, Parit Raja 86400 Batu Pahat Johor; siewyee0519@gmail.com (L.S.Y.); tclee@uthm.edu.my (L.T.C.);

3 Department of Chemical and Biology, Faculty of Science and Technology, University Tun Hussein Onn Malaysia, Pagoh Education Hub, 84600, Pagoh, Muar, Johor, Malaysia; hatijah@uthm.edu.my (H.B.);

* Correspondence: amirulfaizabdlatif@gmail.com (A.F.A.L.);

Scopus Author ID 57216974775

Received: 10.03.2021; Revised: 10.04.2021; Accepted: 13.04.2021; Published: 20.04.2021

Abstract: Substantial utilization of heavy metals in various industrial processes nowadays had cause heavy metal pollutions in the water. Hexavalent chromium, $\mathrm{Cr}$ (VI), is one of the heavy metals which has been extensively used in alloy pigment production and surface treatment. The present work reports natural adsorbent synthesis made from eggshell to reduce $\mathrm{Cr}$ (VI) in water. The eggshell adsorbents were prepared by several steps that include boiling, drying, calcination at $900{ }^{\circ} \mathrm{C}$, grinding, $\mathrm{pH}$ adjustment, precipitation, and filtration. XRD results displayed a highly crystalline hydroxyapatite (HAp) peak that was successfully synthesized. FESEM analysis showed the morphology of the powder that was agglomerate with irregular cloud-like shapes, while EDS results presented the elements in the eggshell powders that include calcium $(\mathrm{Ca})$, phosphorus $(\mathrm{P})$, and oxygen $(\mathrm{O})$. FTIR analysis revealed the presence of hydroxyl group ( $\mathrm{OH}-)$ that contribute to the adsorption process. The adsorption experiment demonstrates the highest $\mathrm{Cr}$ (VI) removal and adsorption capacity of $70 \%$ and $285.71 \mathrm{mg} / \mathrm{g}$, respectively, was attained by $6 \mathrm{~g}$ adsorbent dosage within 1 hour. Kinetic studies of the adsorption process were best described by the pseudo-second-order model and Langmuir isotherm model with a high correlation coefficient of 0.98 . This work's findings suggested that eggshells are potential natural adsorbent to reduce heavy metal pollutions, specifically $\mathrm{Cr}(\mathrm{VI})$ in water.

Keywords: hydroxyapatite; eggshells; chromium; adsorbent.

(C) 2021 by the authors. This article is an open-access article distributed under the terms and conditions of the Creative Commons Attribution (CC BY) license (https://creativecommons.org/licenses/by/4.0/).

\section{Introduction}

Globalization may have brought to the rapid advancement of industrial activities but at the same time also inflicts serious damage to the environment. Industries are the main contributor to releasing toxic waste materials in solid, liquid, and gaseous forms directly into our ecosystem [1]. Toxic waste materials generally contain heavy metals, metalloids, and organic pollutants that can cause severe damage to the soil and water systems. Heavy metal pollution into the water is one of the never-ending issues that pose a serious threat to human health and the environment [2]. 
The concern towards heavy metal pollution has increased over the past decades, and the most toxic listed contaminant by the United States Environment Protection Agency was hexavalent chromium $(\mathrm{Cr}(\mathrm{VI}))[3,4]$. $\mathrm{Cr}(\mathrm{VI})$ is a transition element that is naturally found in rocks and soil. $\mathrm{Cr}$ has an oxidation number between $\mathrm{Cr}^{2-}$ and $\mathrm{Cr}^{6+}$, but it is commonly found in nature as trivalent $\left[\mathrm{Cr}^{3+}\right.$ or $\left.\mathrm{Cr}(\mathrm{III})\right]$ and hexavalent $\mathrm{Cr}\left[\mathrm{Cr}^{6+}\right.$ or $\left.\mathrm{Cr}(\mathrm{VI})\right]$ [1]. Chromium was massively utilized in various industrial activities, including metallurgy, refractory, electroplating, and production of chromium-containing compounds, such as pigments, paints, catalysts, chromic acid, and tanning agents. This had caused the widespread presence of chromium in the ecosystem [5]. Cr (VI) is a strong oxidizing agent and highly toxic chemical substances that can cause a various potential health risk, including cancer, skin rashes, respiratory problems, vomiting, weakened immune system, epigastric pain, nausea, kidney and liver damage, as well as alternation of genetic materials [6]. In 2004, World Health Organization (WHO) had established a maximum allowable limit of $50 \mu \mathrm{g} / \mathrm{L}$ for $\mathrm{Cr}$ (VI) concentration in drinking water [7].

Intense research efforts have been conducted to find out the most effective methods to remove $\mathrm{Cr}(\mathrm{VI})$ in water. The potential treatment methods include ion exchange, chemical precipitation electrochemical method, biological treatment, filtration, and adsorption process [8]. Among these methods, adsorption is highly preferred owing to its low operational cost and excellent efficiency in removing heavy metals [9]. The adsorption process can be defined as the assortment of gas or liquid matter in molecules, atoms, or ions on the surface of another solid substance. It could be a physical or chemical association of material molecules in the active sites of a surface through the Van der Waals force that existed between the molecules [10]. The adsorption process can be influenced by various factors such as temperature, $\mathrm{pH}$, contact time, initial concentration, and surface area [11]. The mechanism of the adsorption process can be further described through kinetic and isotherm adsorption study. Commonly, pseudo-first-order and pseudo-second-order are used in kinetic adsorption study, while Langmuir and Freundlich are widely used in isotherm study [10]. The adsorption efficiency depends on the surface area, surface morphology, pore size distribution, polarity, and functional groups of the adsorbent [12]. Adsorbents can be extracted from natural resources or chemically synthesized in the laboratory. Natural resources such as corals, eggshells, sea mussels, bovine bone, and sheep bone have been intensive studies as adsorbent to remove heavy metal pollution [11].

The use of eggshells to produce low-cost adsorbents is a promising approach to tackle heavy metal problems, given the high content of eggshells' calcium carbonate. Furthermore, large amounts of eggshells waste from industrial and domestic usage make adsorbent production from this waste an environmentally-friendly method [13]. This can reduce the environmental impacts caused by the massive disposal of eggshells to landfills. Eggshell is a calcium-rich shell source that mainly consists of calcium carbonate $\left(\mathrm{CaCO}_{3}\right)$. Consequently, eggshells could be further synthesized and transformed into valuable Ca-based compounds such as hydroxyapatite (HAp), tri-calcium phosphate (TCP), calcite $\left(\mathrm{CaCO}_{3}\right)$, and calcium hydroxide $\mathrm{Ca}(\mathrm{OH})_{2}$ [14]. Owing to its unique morphology and ion exchange sites provided by $\mathrm{Ca}^{2+}$ ions, HAp is considered a promising adsorbent material [9]. These characteristics provide HAp its high-sorption capacity for heavy metal ions, low water solubility, and high stability. The three adsorption mechanisms reaction is ion exchange, dissolution, and formation of surface complexes with calcium and hydroxyl groups [8]. Many HAp-based adsorbents show high efficiency in removing $\mathrm{Cr}$ (VI) recorded, including whey protein waste (81\%), guar gum 
(98\%), sugarcane bagasse (87\%), wheat bran (90\%), and java plum $(99 \%)[10,15]$. HAp derived from eggshells has also been successfully proven to remove various contaminants, including heavy metals and dyes, with removal efficiency between 94\% and 98\% [16]. The porous structure of the eggshell makes it an excellent natural bio-adsorbent for removing heavy metal ions from wastewater [17]. Many studies have proven the effectiveness of eggshells in removing heavy metals, including cadmium [18], copper, zinc [19], and lead [20].

This study aims to highlight the synthesis action of eggshells to produce natural adsorbents and investigate the adsorbent's performances by adsorption and kinetic studies for the application $\mathrm{Cr}(\mathrm{VI})$ removal in water.

\section{Materials and Methods}

\subsection{Synthetization of eggshell adsorbents.}

Eggshells were obtained from Hainanese Café, located at Parit Raja, Batu Pahat, Johor, Malaysia. The process started with pretreatment of the eggshells by boiling with double distilled water for 30 minutes at $100{ }^{\circ} \mathrm{C}$ to ensure the removal of dirt and other impurities. Then, the eggshells were dried in an oven at $80^{\circ} \mathrm{C}$ for 2 hours. After that, the dried eggshells were calcined at $900{ }^{\circ} \mathrm{C}$ for one hour. Subsequently, the calcined eggshells were finely ground, dispersed in distilled water, and treated with $0.6 \mathrm{M}$ phosphoric acid solution before left to precipitate for 24 hours. After 24 hours, the solution was stirred for 30 minutes with a magnetic stirrer and left for another 24 hours to complete precipitation formation. Lastly, the precipitate was filtered and dried in an oven at $100{ }^{\circ} \mathrm{C}$ for 2 hours.

\subsection{Characterisation of eggshells adsorbent.}

The morphology of the obtained eggshell powders was examined using field emission scanning electron microscopy (FESEM) (JFM- 7600F, JEOL, $15.0 \mathrm{kV}$ ). The powder's elemental composition was examined using an energy dispersive X-ray spectrometer (EDS) (SU1510, Hitachi, $15.0 \mathrm{kV}$ ). The mineralogy was analyzed using X-ray diffraction (XRD) (X'pert-PanAnalytical, Bruker Advance D8 Advance), at an angle of incidence $1^{\circ} 2 \theta$ and scanning step $0.02^{\circ} 2 \theta$. Fourier transform infrared spectroscopy (FTIR) (Bruker Vector 22 midIR spectroscopy) was used to examine the synthesized powders' functional groups. The spectra were recorded for the range of $4000-400 \mathrm{~cm}^{-1}$.

\subsection{Adsorption experiment.}

The adsorption experiment is conducted to assess the eggshell powders' performance as adsorbents for the removal of $\mathrm{Cr}$ (IV). Initially, 300mg/L of $\mathrm{Cr}$ (IV) stock solution was prepared by dissolving potassium dichromate (ChemAR) in $1000 \mathrm{~mL}$ of volumetric flask. Then, the potassium dichromate solution was diluted into a desirable concentration in a 1000 Ml volumetric flask. Next, the Cr (IV) solution was spiked into $250 \mathrm{ml}$ conical flask together with eggshells adsorbent. After that, the sample was shaken in an orbital shaker at $650 \mathrm{rpm}$. The effects of adsorbent dosage and contact time were investigated toward Cr (IV) removal. At a certain time interval of shaking, the sample was collected and filter before be analyzed for $\mathrm{Cr}$ (IV) concentration using UV-Visible spectroscopy at a wavelength of $540 \mathrm{~nm}$ [21].

The amount of $\mathrm{Cr}$ (IV) adsorbed per gram and percentage of $\mathrm{Cr}$ (IV) removal by the eggshells adsorbent was calculated by using Eq. 1 and 2, respectively [22] 


$$
\begin{aligned}
& \mathrm{q}_{\mathrm{e}}=\frac{\mathrm{V}\left(\mathrm{C}_{\mathrm{o}}-\mathrm{C}_{\mathrm{e}}\right)}{\mathrm{W}} \\
& \text { Adsorption }(\%)=\frac{\left(\mathrm{C}_{0}-\mathrm{C}_{\mathrm{e}}\right)}{\mathrm{C}_{\mathrm{o}}} \times 100
\end{aligned}
$$

where $\mathrm{q}_{\mathrm{e}}(\mathrm{mg} / \mathrm{g})$ is the amount of metal ions, $\mathrm{V}$ is the solution volume $(\mathrm{L}), \mathrm{W}$ is the adsorbent dose $(\mathrm{g}), \mathrm{C}_{\mathrm{o}}(\mathrm{mg} / \mathrm{l})$ is the initial $\mathrm{Cr}(\mathrm{IV})$ concentration and $\mathrm{C}_{\mathrm{e}}(\mathrm{mg} / \mathrm{L})$ is the equilibrium $\mathrm{Cr}(\mathrm{IV})$ concentration in solution.

\section{Results and Discussion}

\subsection{FESEM analysis.}

The FESEM micrograph of adsorbent before and after adsorption of $\mathrm{Cr}$ (VI) are shown in Figure 1. It is observed that the powder was agglomerated with irregular cloud-like shapes and had some pores in between. It could be explained by comparing Figure 3(A) and Figure 3(B) that the chromium occupies the adsorbent's free pores. The formation of pores is beneficial for adsorbents to adsorb $\mathrm{Cr}$ (VI) as they provide more active sites for adsorption to effectively occur [23]. It is found that the porous structure morphology is significantly effective in the removal of heavy metals, including chromium, vanadium, and ammonium, in water [24]. Similar results have been reported by Momen et al. [13] and Shekari et al. [10,25].
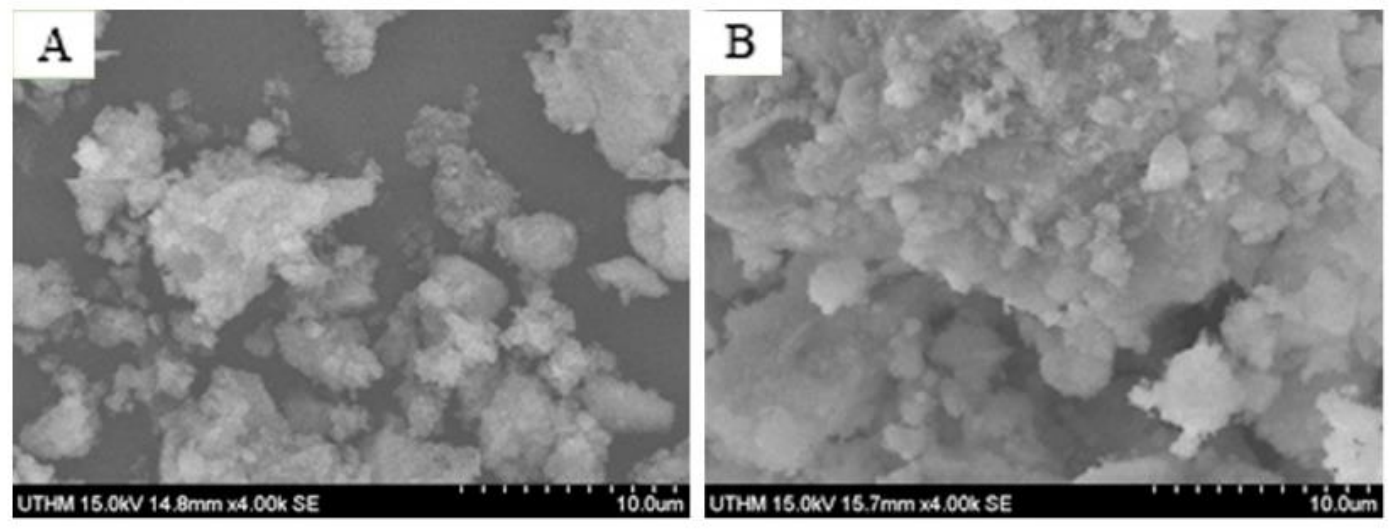

Figure 1. FESEM micrographs of eggshells powder (A) before and (B) after adsorption.

\subsection{XRD analysis.}

The XRD analysis of the eggshell powders is shown in Figure 2. The XRD patterns show the formation of HAp peaks that were validated by comparing them to the standard HAp (ICDD 00-003-0747). The pure crystalline HAp corresponded to the standard HAp peaks where the strongest intensity peaks can be found at the angle of incidence $1^{\circ} 2 \theta$ and scanning step $0.02^{\circ} 2 \theta$. The formation of crystalline HAp is due to the hydrothermal process after calcination, giving greater intensity in the formation of peaks [26]. It is proven that higher temperatures provide matrix stability and enhancement of crystallinity [27]. The crystallinity of the HAp structure significantly influenced the good bioactivity and flexible structure of adsorbents. This confirms that HAp is successfully formed via calcination at $900{ }^{\circ} \mathrm{C}$ and chemical precipitation of the eggshells and potential to be used as an adsorbent to remove $\mathrm{Cr}$ (VI). 


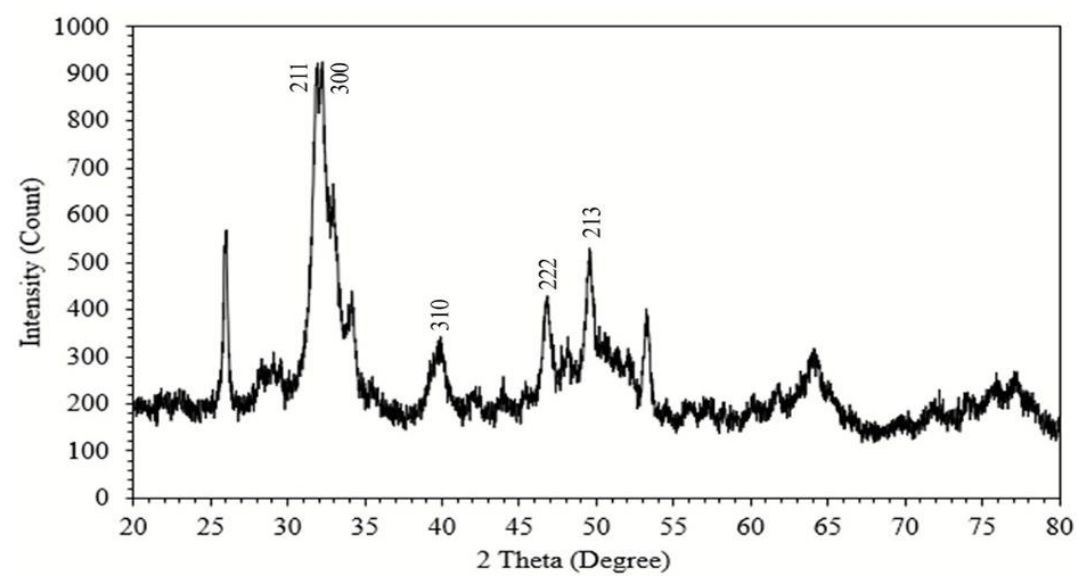

Figure 2. XRD pattern of HAp peak of eggshells powders.

\subsection{EDS analysis.}

Figure 3 shows the elemental composition of the eggshell powders via EDS analysis. The elements that present in the samples include calcium $(\mathrm{Ca})$, phosphorus $(\mathrm{P})$, and oxygen (O). Based on the result, the $\mathrm{Ca} / \mathrm{P}$ ratio can be calculated, which is 1.56 . The powder sample does not reach the theoretical value of $\mathrm{Ca} / \mathrm{P}$ ratio of 1.67 due to the $\mathrm{pH}$ value carried out in this work. The ideal $\mathrm{pH}$ to synthesis HAp is between 9.5 to 12 [28] and not 8.5 as carried out in this study. The $\mathrm{pH}$ values and reaction temperature have been recognized as the most vital factors which could affect the chemical and physical properties of HAp powder during the precipitation process [29]. The $\mathrm{pH}$ value significantly affecting the monetite phase, thus enhanced the changes in $\mathrm{Ca} / \mathrm{P}$ ratio [30].

\subsection{FTIR analysis.}

Figure 4 shows the FTIR spectra of eggshell powders. The nonstoichiometric HAp characteristics are observed from phosphate $\left(\mathrm{PO}_{4}{ }^{3}-\right)$, carbonate $\left(\mathrm{CO}_{3}{ }^{2-}\right)$, hydroxide $(\mathrm{OH}-)$, as well as hydrogen phosphate $\left(\mathrm{HPO}_{4}{ }^{2-}\right)$. The absorption peaks at 873.88 and $1019.72 \mathrm{~cm}^{-1}$ are assigned to $\mathrm{PO}_{4}^{3-}$ vibration, and the peak at $1642.96 \mathrm{~cm}^{-1}$ is attributed to $\mathrm{H}_{2} \mathrm{O}$ physically adsorbed. There is a broad peak in the region of $3370.16 \mathrm{~cm}^{-1}$, coming from the $\mathrm{OH}$ - group's stretching vibration. The hydroxyl group's presence is due to the $\mathrm{OH}$ group in the structure of HAp [31]. Hydroxyl group is vital in the adsorption process as it permits the formation of hydrogen bridges which would cause the polar functional groups to be directed into the body of the adsorbent. This creates an important active site for adsorption to effectively occur [32]. The bands corresponding to $\mathrm{CO}_{3}{ }^{2-}$ vibration is observed around $1416.00 \mathrm{~cm}^{-1}$ which is due to the absorption of $\mathrm{CO}_{2}$ from the air.

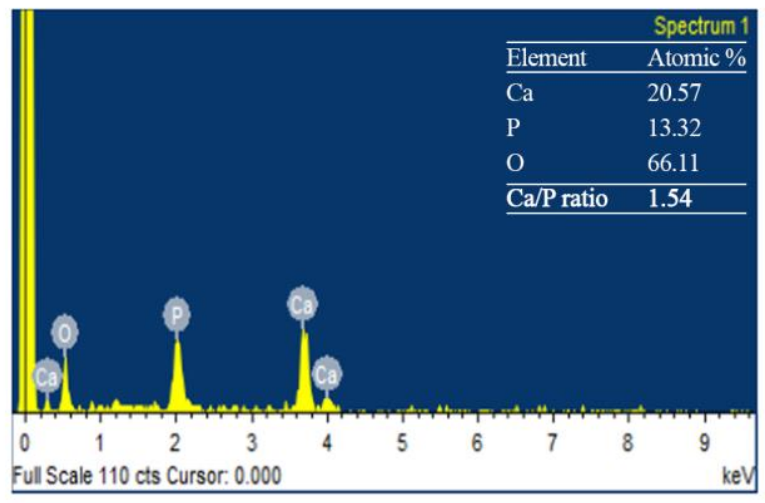

Figure 3. The EDS spectrum of eggshell powder. 


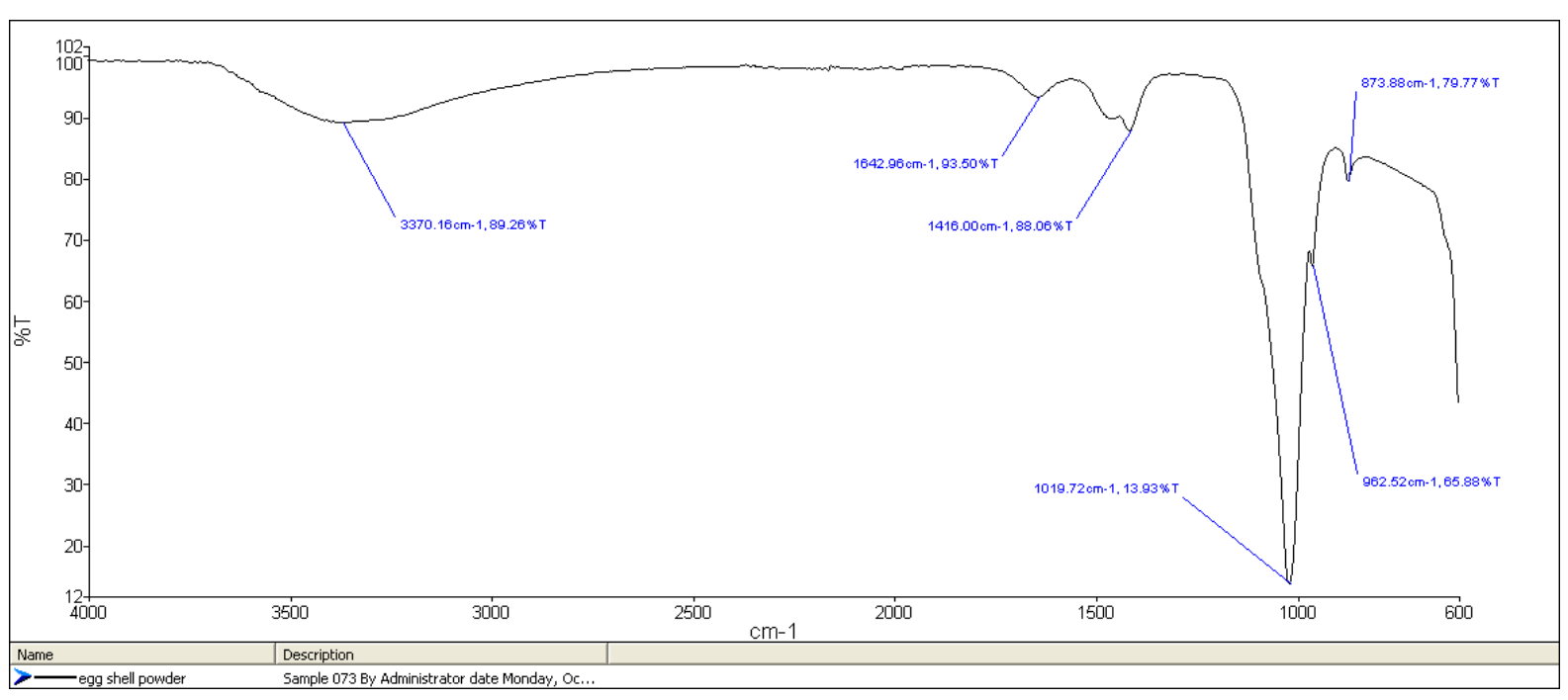

Figure 4. The FTIR analysis for initial eggshell powder.

\section{5. $\mathrm{Cr}(\mathrm{VI})$ removal by adsorption process.}

Figure 5 shows the $\mathrm{Cr}$ (VI) removal rate by eggshells of different adsorbent dosages within 60 minutes. The lowest adsorbent dosage of $1 \mathrm{~g}$ showed the lowest $\mathrm{Cr}$ (VI) removal rate of $5.92 \%$. As the dosage increased, the removal rate also increased and reached the maximum of $70.03 \%$ at $6 \mathrm{~g}$ adsorbent dosage. The removal rate for 2 to $4 \mathrm{~g}$ dosage is $9.61 \%, 19.18 \%$, $33.35 \%$ and $58.34 \%$ respectively. These results are consistent with FESEM results in which the removal of $\mathrm{Cr}$ (VI) increased with the increase in the amount of adsorbent dosage. Higher adsorbent dosage permits a greater surface area availability and more adsorption regions for $\mathrm{Cr}$ (VI) [24].

\subsection{Isotherm adsorption study.}

The two most widely applied isotherm models, Langmuir and Freundlich, were used to determine the adsorbent's sorption capacity in removing $\mathrm{Cr}(\mathrm{VI})$ [10]. The Langmuir adsorption isotherm is based on monolayer adsorption of metal ions on the surface of the adsorbent, and the energy of the adsorption system is considered constant. Meanwhile, Freundlich isotherm was developed for the heterogeneous system that implies the concept of multilayer adsorption on the surface of adsorbent [33]. From the Langmuir adsorption constant, the adsorption capacity, $\mathrm{q}_{\max }$ for $\mathrm{Cr}(\mathrm{VI})$ is $15.53 \mathrm{mg} / \mathrm{g}$ and higher than other low-cost bio adsorbents [17]. The $\mathrm{R}_{\mathrm{L}}$ : 0.058, which lies between 0 and 1, indicates that the Langmuir isotherm is favorable [21]. As for Freundlich isotherm, the Freundlich affinity constant $\left(K_{f}\right)$ was found to be 2.93 . The $K_{f}$ lies between 1 and 10 show the removal of $\mathrm{Cr}$ (VI) using eggshells adsorbent is favorable [34]. In this study, the heterogeneity parameter $(1 / \mathrm{n})$ is 0.47 indicates a normal distribution of the energy sites, which confirms that the adsorption condition was favorable [35]. The corresponding Langmuir and Freundlich isotherms plots are shown in Figure 6. The parameters for Langmuir and Freundlich listed in Table 1 show both plots have high correlation coefficients $\left(\mathrm{R}^{2}=0.98,0.97\right)$. The fact that the values of the correlation constant were higher for the Langmuir model relative to the Freundlich isotherm indicates the Langmuir isotherm's greater suitability. 

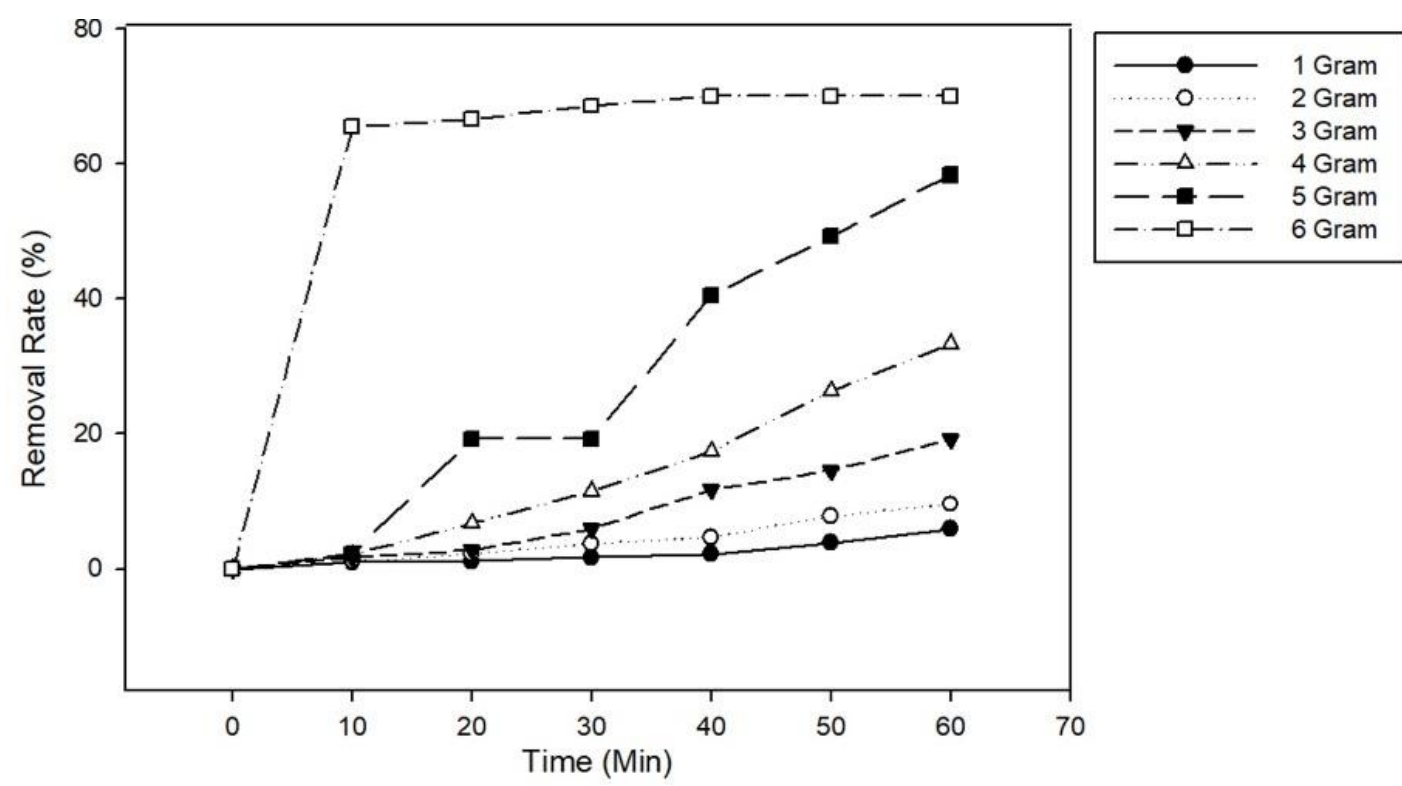

Figure 5. Effect of eggshells adsorbent dosage on Cr (VI) removal.
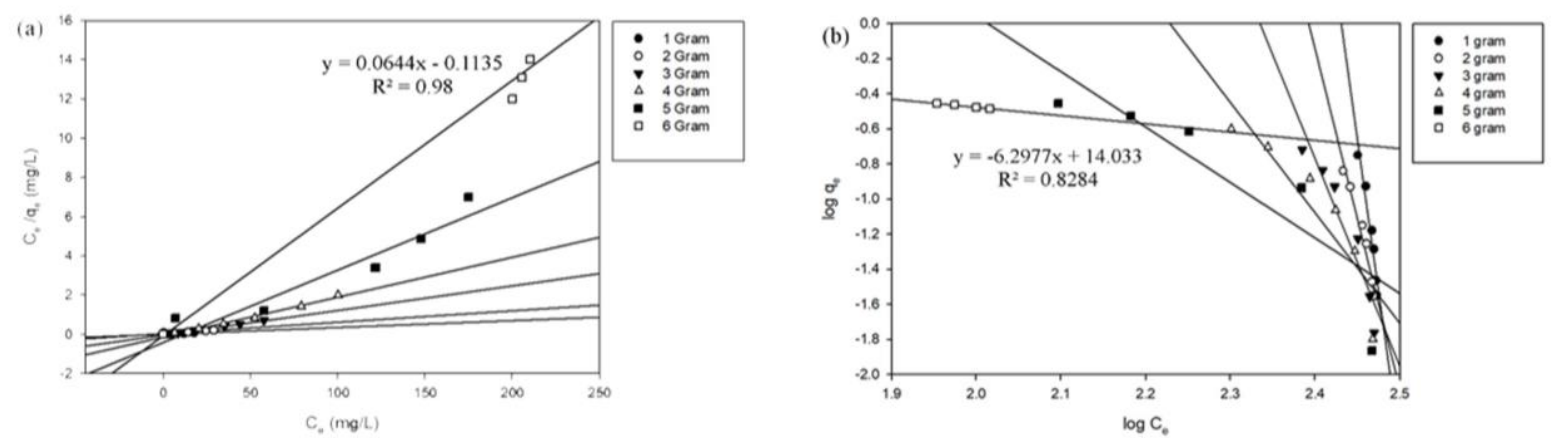

Figure 6. Adsorption of Cr (VI) by (a) Langmuir and (b) Freundlich isotherm model.

Table 1. Langmuir and Freundlich constants and correlation coefficients for adsorption of Cr (VI).

\begin{tabular}{c|c|c|c|c|c|c} 
Langmuir & \multicolumn{3}{l}{ Freundlich } \\
\hline $\mathrm{q}_{\max }$ & $\mathrm{b}$ & $\mathrm{R}^{2}$ & $\mathrm{R}_{\mathrm{L}}$ & $\mathrm{K}_{\mathrm{F}}$ & $1 / \mathrm{n}$ & $\mathrm{R}^{2}$ \\
\hline 15.528 & 0.568 & 0.98 & 0.006 & 2.93 & 0.47 & 0.97
\end{tabular}

\subsection{Kinetic adsorption study.}

Sorption kinetic models are used to identify the mechanism of kinetic adsorption in this study. The pseudo-first-order is used for the liquid/solid system in which the surfaces changes rates are proportional to the remaining amount of surface sites. On the contrary, the pseudosecond-order model is in which the rate is proportional to the square surface sites $[15,36]$. Figure 7 shows the linearized plots of the pseudo-first-order model and the pseudo-secondorder model. $\mathrm{K}_{1}, \mathrm{~K}_{2}$, and $\mathrm{q}_{\mathrm{e}}$ are calculated from the slopes and listed in Table 2. The pseudosecond-order model fits better for the adsorption kinetics of $\mathrm{Cr}$ (VI) ion on eggshell adsorbents than the pseudo-first-order model. The correlation coefficient of pseudo-second-order model is higher $\left(\mathrm{R}^{2}=0.999\right)$ than pseudo-first-order model $\left(\mathrm{R}^{2}=0.672\right)$. This indicates that the ratelimiting step for the sorption process may be chemical sorption or chemisorption involving valency forces by sharing or exchanging electrons between sorbent and sorbate [37]. The maximum $\mathrm{Cr}$ (VI) ion adsorbed qe was found to be $285.71 \mathrm{mg} / \mathrm{g}$. The adsorbent shows high adsorption capacity for $\mathrm{Cr}$ (VI) which was recorded in several studies; $104 \mathrm{mg} / \mathrm{g}$ [38], 374.53 $\mathrm{mg} / \mathrm{g}$ [39] and $417.19 \mathrm{mg} / \mathrm{g}$ [40]. 

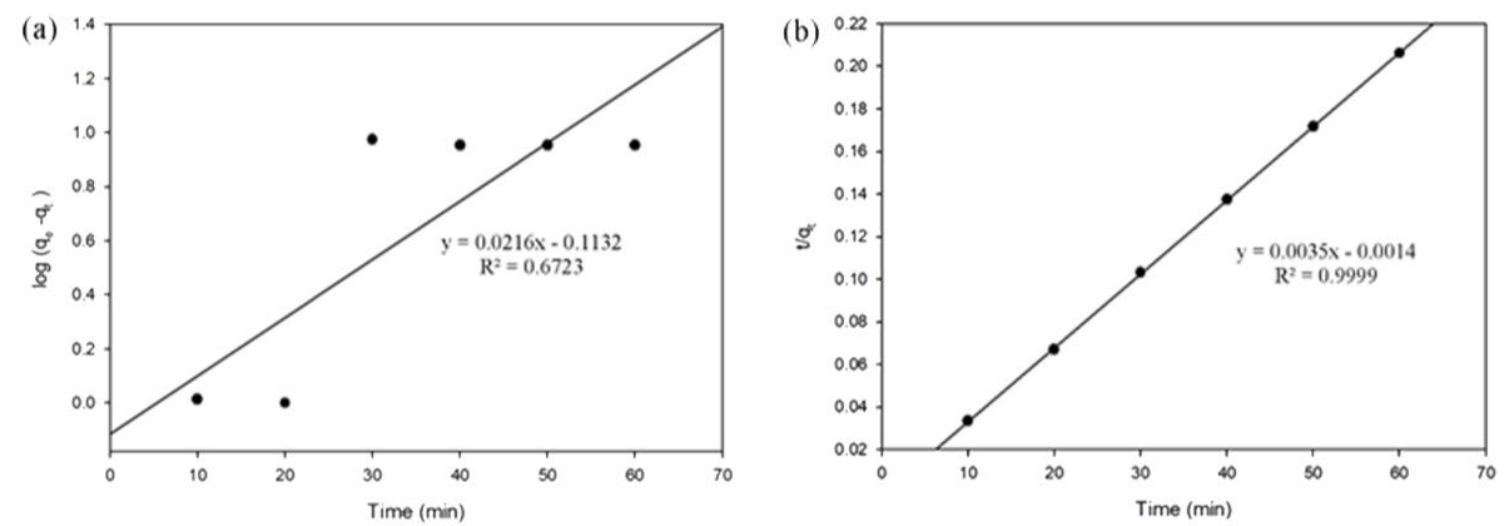

Figure 7. Linearized plot of experimental data using (a) pseudo-first-order model and (b) pseudo-second-order model.

Table 2. Parameters of pseudo-first-order and pseudo-second-order models.

\begin{tabular}{c|c|c|c|c|c} 
Pseudo-First-Order & Pseudo-Second-Order \\
\hline $\mathrm{q}_{\mathrm{e}}$ & $\mathrm{K}_{1}$ & $\mathrm{R}^{2}$ & $\mathrm{q}_{\mathrm{e}}$ & $\mathrm{K}_{2}$ & $\mathrm{R}^{2}$ \\
\hline 1.297 & 0.0497 & 0.672 & 285.71 & 0.0087 & 0.999
\end{tabular}

\section{Conclusions}

The synthesis of eggshells by calcination can produce HAp that acts as an adsorbent for removing $\mathrm{Cr}$ (VI) in water. XRD analysis confirms the HAP peaks. FTIR analysis displays a hydroxyl group that significantly contributes to the adsorption process. The $\mathrm{Ca} / \mathrm{P}$ ratio recorded is 1.56. The surface morphology of the eggshells adsorbent shows significant pores formation that enhances the adsorption process. The adsorption experiment revealed that increased eggshells adsorbent dosage contributes to increased Cr (VI) removal up to $70 \%$ with 285.71 $\mathrm{mg} / \mathrm{g}$ adsorption capacity as recorded by $6 \mathrm{~g}$ dosage sample, owing to the availability of surface area that permits more biosorption regions. Natural adsorbents synthesized from eggshells can reduce heavy metal concentration in water and minimize the problem of waste disposal to landfills.

\section{Funding}

This research was funded by the Ministry of Higher Education (MOHE), Malaysia, through Fundamental Research Grant Scheme grant K219 (FRGS/1/2019/TK10/UTHM/03/3) and University Tun Hussein Onn Malaysia through GPPS grant (H596).

\section{Acknowledgments}

The authors wish to thank the Ministry of Higher Education (MOHE), Malaysia, for the financial support from the Fundamental Research Grant Scheme grant (K219) (FRGS/1/2019/TK10/UTHM/03/3) and Universiti Tun Hussein Onn Malaysia for the GPPS grant (H596).

\section{Conflicts of Interest}

The authors declare no conflict of interest. 


\section{References}

1. Nur-E-Alam, M.; Mia, M.A.S.; Ahmad, F.; Rahman, M.M. An Overview of Chromium Removal Techniques from Tannery Effluent. Appl. Water Sci. 2020, 2020, 10. https://doi.org/10.1007/s13201-020-01286-0.

2. Elahi, A.; Arooj, I.; Bukhari, D.A.; Rehman, A. Successive Use of Microorganisms to Remove Chromium from Wastewater. Appl. Microbiol. Biotechnol. 2020, 104, 3729-3743. https://doi.org/10.1007/s00253-02010533-y.

3. Mane, C.P.; Mahamuni, S. V; Kolekar, S.S.; Han, S.H.; Anuse, M.A. Hexavalent Chromium Recovery by Liquid - Liquid Extraction with 2-Octylaminopyridine from Acidic Chloride Media and Its Sequential Separation from Other Heavy Toxic Metal Ions. Arab. J. Chem. 2016, 9, S1420-S1427. https://doi.org/10.1016/j.arabjc.2012.03.021.

4. Ahmed, M.F.; Mokhtar, M. Bin Assessing Cadmium and Chromium Concentrations in Drinking Water to Predict Health Risk in Malaysia. 2020, 17, 2966. https://doi.org/10.3390/ijerph17082966.

5. Alemu, A.; Lemma, B.; Gabbiye, N.; Tadele, M.; Teferi, M. Removal of Chromium (VI) from Aqueous Solution Using Vesicular Basalt: A Potential Low Cost Wastewater Treatment System. Heliyon 2018, 4 , e00682. https://doi.org/10.1016/j.heliyon.2018.e00682.

6. Te Chuan, L.; Manap, N.; Zuhudi Abdullah, H.; Izwana Idris, M. Polyvinyl Alcohol-Alginate Adsorbent Beads for Chromium (VI) Removal. Int. J. Eng. Technol. 2018, $7, \quad 95$. https://doi.org/10.14419/ijet.v7i3.20.18988.

7. Rani, N.; Singh, B.; Shimrah, T. Chromium (VI) Removal from Aqueous Solutions Using Eichhornia as an Adsorbent. J. Water Reuse Desalin. 2017, 7, 461-467. https://doi.org/10.2166/wrd.2016.094.

8. Liu, W.; Liaw, B.; Chang, H.; Wang, Y.; Chen, P. From Waste to Health: Synthesis of Hydroxyapatite Scaffolds From Fish Scales for Lead Ion Removal. JOM 2017, 69, 713-718. https://doi.org/10.1007/s11837017-2270-5.

9. Xia, X.; Shen, J.; Cao, F.; Wang, C.; Tang, M.; Zhang, Q.; Wei, S. A Facile Synthesis of Hydroxyapatite for Effective Removal Strontium Ion. J. Hazard. Mater. 2019, 368, 326-335. https://doi.org/10.1016/j.jhazmat.2019.01.040.

10. Momen, A.H.A.; Nur, M.H.S.; Sheikh, A.T.H.R. Chromium Removal from Tannery Wastewater Using Syzygium Cumini Bark Adsorbent. Int. J. Environ. Sci. Technol. 2018, 16, 1395-1404. https://doi.org/10.1007/s13762-018-1714-y.

11. Komur, B.; Altun, E.; Aydogdu, M.O.; Bilgiç, D.; Gokce, H.; Ekren, N. Hydroxyapatite Synthesis from Fish Bones : Atlantic Salmon ( Salmon Salar ). 2017, 131, 400-402. https://doi.org/10.12693/APhysPolA.131.400.

12. Ma, H.; Yang, J.; Gao, X.; Liu, Z.; Liu, X.; Xu, Z. Removal of Chromium (VI) from Water by Porous Carbon Derived from Corn Straw: Influencing Factors, Regeneration and Mechanism. J. Hazard. Mater. 2019, 369, 550-560. https://doi.org/10.1016/j.jhazmat.2019.02.063.

13. Laca, A.; Laca, A.; Díaz, M. Eggshell Waste as Catalyst: A Review. J. Environ. Manage. 2017, 197, 351359. https://doi.org/10.1016/j.jenvman.2017.03.088.

14. Ummartyotin, S.; Manuspiya, H. A Critical Review of Eggshell Waste: An Effective Source of Hydroxyapatite as Photocatalyst. J. Met. Mater. Miner. 2018, 28, 124-135. https://doi.org/10.14456/jmmm.2018.17.

15. Khan, T.A.; Nazir, M.; Ali, I.; Kumar, A. Removal of Chromium(VI) from Aqueous Solution Using Guar Gum-Nano Zinc Oxide Biocomposite Adsorbent. Arab. J. Chem. 2017, 10, S2388-S2398. https://doi.org/10.1016/j.arabjc.2013.08.019.

16. Makuchowska-Fryc, J. Use of The Eggshells in Removing Heavy Metals from Waste Water - The Process Kinetics and Efficiency. Ecol. Chem. Eng. S 2019, 26, 165-174. https://doi.org/10.1515/eces-2019-0012.

17. Sankaran, R.; Show, P.L.; Ooi, C.W.; Ling, T.C.; Shu-Jen, C.; Chen, S.Y.; Chang, Y.K. Feasibility Assessment of Removal of Heavy Metals and Soluble Microbial Products from Aqueous Solutions Using Eggshell Wastes. Clean Technol. Environ. Policy 2020, 22, 773-786. https://doi.org/10.1007/s10098-01901792-z.

18. Tizo, M.S.; Blanco, L.A. V.; Cagas, A.C.Q.; Dela Cruz, B.R.B.; Encoy, J.C.; Gunting, J. V.; Arazo, R.O.; Mabayo, V.I.F. Efficiency of Calcium Carbonate from Eggshells as an Adsorbent for Cadmium Removal in Aqueous Solution. Sustain. Environ. Res. 2018, 28, 326-332. https://doi.org/10.1016/j.serj.2018.09.002.

19. Lin, T.Y.; Chai, W.S.; Chen, S.J.; Shih, J.Y.; Koyande, A.K.; Liu, B.L.; Chang, Y.K. Removal of Soluble Microbial Products and Dyes Using Heavy Metal Wastes Decorated on Eggshell. Chemosphere 2020, 270, 128615. https://doi.org/10.1016/j.chemosphere.2020.128615. 
20. Zhang, T.; Tu, Z.; Lu, G.; Duan, X.; Yi, X.; Guo, C.; Dang, Z. Removal of Heavy Metals from Acid Mine Drainage Using Chicken Eggshells in Column Mode. J. Environ. Manage. 2017, 188, 1-8. https://doi.org/10.1016/j.jenvman.2016.11.076.

21. Erabee, I.K. Removal of Ammonia Nitrogen NH-N and Hexavalent Chromium (VI) from Wastewater Using Agricultural Waste Activated Carbon. Orient. J. Chem. 2018, 34, 1033-1040. https://doi.org/10.13005/ojc/340254.

22. Nordin, N.; Amirah, N.; Asmadi, A.; Manikam, M.K.; Halim, A.A.; Hanafiah, M.M.; Hurairah, S.N. Removal of Hexavalent Chromium from Aqueous Solution by Adsorption on Palm Oil Fuel Ash ( POFA ). Journal and Geoscience and Environment Protection 2020, 8, 112-127. https://doi.org/10.4236/gep.2020.82008.

23. Khandelwal, H.; Prakash, S. Synthesis and Characterization of Hydroxyapatite Powder by Eggshell. J. Miner. Mater. Charact. Eng. 2016, 04, 119-126. http://dx.doi.org/10.4236/jmmce.2016.42011.

24. Fang, D.; Zhang, X.; Dong, M.; Xue, X. A Novel Method to Remove Chromium, Vanadium and Ammonium from Vanadium Industrial Wastewater Using a Byproduct of Magnesium-Based Wet Flue Gas Desulfurization. J. Hazard. Mater. 2017, 336, 8-20. https://doi.org/10.1016/j.jhazmat.2017.04.048.

25. Shekari, H.; Sayadi, M.H.; Rezaei, M.R.; Allahresani, A.. Synthesis of nickel ferrite/titanium oxide magnetic nanocomposite and its use to remove hexavalent chromium from aqueous solutions, Surfaces and Interfaces 2017, 8, 199-205. https://doi.org/10.1016/j.surfin.2017.06.006.

26. Mohamad Razali, N.A.I.; Pramanik, S.; Abu Osman, N.A.; Radzi, Z.; Pingguan-Murphy, B. Conversion of Calcite from Cockle Shells to Bioactive Nanorod Hydroxyapatite for Biomedical Applications. J. Ceram. Process. Res. 2016, 17, 699-706. https://doi.org/10.36410/jcpr.2016.17.7.699.

27. Mondal, B.; Mondal, S.; Mondal, A.; Mandal, N. Fish Scale Derived Hydroxyapatite Scaffold for Bone Tissue Engineering. Mater. Charact. 2016, 121, 112-124. http://dx.doi.org/10.1016/j.matchar.2016.09.034.

28. Kamrujjaman, M.; Ji, K.; Mm, H.; Mo, R. Study of the Dependency of PH Values on HAp Synthesis. 2019. https://doi.org/10.4172/2324-8777.1000258.

29. Goh, K.W.; Wong, Y.H.; Ramesh, S.; Chandran, H.; Krishnasamy, S.; Sidhu, A.; Teng, W.D. Effect of pH on the Properties of Eggshell-Derived Hydroxyapatite Bioceramic Synthesized by Wet Chemical Method Assisted by Microwave Irradiation. Ceram. Int. 2020, 47, 8879-8887. https://doi.org/10.1016/j.ceramint.2020.12.009.

30. Rodríguez-Lugo, V.; Karthik, T.V.K.; Mendoza-Anaya, D.; Rubio-Rosas, E.; Villaseñor Cerón, L.S.; ReyesValderrama, M.I.; Salinas-Rodríguez, E. Wet Chemical Synthesis of Nanocrystalline Hydroxyapatite Flakes: Effect of PH and Sintering Temperature on Structural and Morphological Properties. R. Soc. Open Sci. 2018, 5. https://doi.org/10.1098/rsos.180962.

31. Ahmad Fara, A.N.K.; bin Yahya, M.A.; Abdullah, H.Z. Preparation and Characterization of Biological Hydroxyapatite (HAp) Obtained from Tilapia Fish Bone. Adv. Mater. Res. 2015, 1087, $152-156$. https://doi.org/10.4028/www.scientific.net/AMR.1087.152.

32. Sudiono, S.; Yuniarti, M.; Siswanta, D.; Kunarti, E.S.; Santosa, S.J. The Role of Carboxyl and Hydroxyl Groups of Humic Acid in Removing AuCl 4 - from Aqueous Solution. Indonesian Journal of Chemistry 2017, 17, 95-104. https://doi.org/10.22146/ijc.23620.

33. Batool, F.; Akbar, J.; Iqbal, S.; Noreen, S.; Bukhari, S.N.A. Study of Isothermal, Kinetic, and Thermodynamic Parameters for Adsorption of Cadmium: An Overview of Linear and Nonlinear Approach and Error Analysis. Bioinorg. Chem. Appl. 2018. https://doi.org/10.1155/2018/3463724.

34. Ngteni, R.; Hossain, M.S.; Kadir, M.O.A.; Asis, A.J.; Tajudin, Z. Kinetics and Isotherm Modeling for the Treatment of Rubber Processing Euent Using Iron (II) Sulphate Waste as a Coagulant. Water 2020, $12,1747$. https://doi.org/10.3390/w12061747.

35. Taylor, P.; Ali, A.; Saeed, K. Decontamination of Cr ( VI ) and Mn ( II ) from Aqueous Media by Untreated and Chemically Treated Banana Peel : A Comparative Study. Desalination and Water Treatment 2014, 53, 37-41. https://doi.org/10.1080/19443994.2013.876669.

36. Liao Dexiang, D.; Zheng, W.; Li, X.; Yang, Q.; Yue, X.; Guo, L.; Zeng, G. Removal of Lead(II) from Aqueous Solutions Using Carbonate Hydroxyapatite Extracted from Eggshell Waste. J. Hazard. Mater. 2010, 177, 126-130. https://doi.org/10.1016/j.jhazmat.2009.12.005.

37. Hubbe, M.A.; Azizian, S.; Douven, S. Implications of Apparent Pseudo-Second-Order Adsorption Kinetics onto Cellulosic Materials: A Review. BioResources 2019, 14, 7582-7626. https://doi.org/10.15376/biores.14.3.7582-7626.

38. Samuel, M.S.; Bhattacharya, J.; Raj, S.; Santhanam, N.; Singh, H.; Pradeep Singh, N.D. Efficient Removal of Chromium(VI) from Aqueous Solution Using Chitosan Grafted Graphene Oxide (CS-GO) 
Nanocomposite. Int. J. Biol. Macromol. 2019, 121, 285-292. https://doi.org/10.1016/j.ijbiomac.2018.09.170.

39. Liu, W.; Yang, L.; Xu, S.; Chen, Y.; Liu, B.; Li, Z.; Jiang, C. Efficient Removal of Hexavalent Chromium from Water by an Adsorption-Reduction Mechanism with Sandwiched Nanocomposites. RSC Adv. 2018, 8 , 15087-15093. https://doi.org/10.1039/C8RA01805G.

40. Gopal Reddi, M.R.; Gomathi, T.; Saranya, M.; Sudha, P.N. Adsorption and Kinetic Studies on the Removal of Chromium and Copper onto Chitosan-g-Maliec Anhydride-g-Ethylene Dimethacrylate. Int. J. Biol. Macromol. 2017, 104, 1578-1585. https://doi.org/10.1016/j.ijbiomac.2017.01.142. 